Mirjana S. Jankulovska*1, Vesna Dimova², llinka Spirevska ${ }^{3}$, Milena Jankulovska ${ }^{4}$

${ }^{1}$ Ss. Cyril and Methodius University, Faculty of Agricultural Sciences and Food, Skopje, North Macedonia, ${ }^{2}$ Ss. Cyril and Methodius University, Faculty of Technology and Metallurgy, Skopje, North Macedonia, ${ }^{3}$ Ss. Cyril and Methodius University, Institute of Chemistry, Faculty of Natural Sciences and Mathematics, Skopje, North Macedonia, ${ }^{4}$ University St. Kliment Ohridski, Faculty of Veterinary Medicine, Skopje, North Macedonia
Scientific paper ISSN 0351-9465, E-ISSN 2466-2585 UDC: $544.146: 544.354 .081 .7: 543.422 .3$ doi: $10.5937 /$ zasmat2101009J

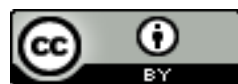

Zastita Materijala $62(1)$ 9 - 21 (2021)

\title{
Comparison of theoretical and experimental investigation of protonation process of some thiones in acid media
}

\begin{abstract}
PM3 semiempirical method was used for quantum chemical investigation in order to investigate the electronic properties and to determine the protonation centre in 1,2,4-triazoline-3-thione molecule. Confirmation of protonation center in acid media of investigated compounds was made using the values of atomic charges, as well as, proton affinity values. The results from semiempirical calculations indicated that the protonation center in the thione molecule was the sulphur atom. The behavior of thiones was investigated in mineral acid media using UV spectroscopy. The influence of the strength of the acid and its anion on the protonation process was discussed using three different mineral acids (perchloric, hydrochloric and phosphoric acid) for protonation. The protonation process in perchloric and hydrochloric acid took place in one step, while in phosphoric acid was not finished even when its concentration was to the highest degree. The dissociation constants of protonated forms $\left(\mathrm{pK}_{\mathrm{BH}}{ }^{+}\right)$and the solvation parameter $\mathrm{m}^{*}$ values were calculated in accordance with „excess acidity” function method (Cox and Yates) using the absorbance data from the experimental and reconstructed spectra (Characteristic Vector Analysis (CVA)). The determined $\mathrm{pK}_{\mathrm{BH}}{ }^{+}$values in hydrochloric acid had more negative value than those obtained in perchloric acid media. The $\mathrm{pK}_{\mathrm{BH}}{ }^{+}$values were in agreement with the literature data for this class of compounds.
\end{abstract}

Keywords: 1,2,4-triazoline-3-thiones, protonation, dissociation constants, proton affinity, UVspectrophotometry, PM3 semiempirical method

\section{INTRODUCTION}

Heterocycles are an important class of compounds which are present in a wide variety of drugs, most vitamins, many natural products, biomolecules, and biologically active compounds. Also, they are significant structural unit in synthetic pharmaceuticals and agrochemicals. The derivatives of 1,2,4-triazole belong to the nitrogen heterocyclic class of compounds which possess aromatic characteristics [1]. In the literature there are a lot of data about synthesis and wide application of compounds that contain triazole ring in their molecule [2,3]. The biological and antiviral activity of these compounds is the result of $-\mathrm{NH}-\mathrm{C}(\mathrm{S})-$ $\mathrm{NH}-$ group in their molecule [4].

\footnotetext{
${ }^{*}$ Corresponding author: Mirjana S. Jankulovska

E-mail: jankulovska_m@yahoo.com

Paper received: 05. 08. 2020.

Paper accepted: 10. 12. 2020.
}

Paper is available on the website: www.idk.org.rs/journal
The compounds that possess triazole ring can be used in medicine as antibacterial, antiviral, analgesic, antiasthmatic and anticancerous drugs as a result of their pharmaceutical properties $[5,6]$. Furthermore, 1,2,4-triazole and its derivatives have found wide use in the chemical industry and agriculture because they posses fungicidal, insecticidal and herbicidal characteristics [7]. Some of the derivatives of triazole showed antioxidant activity [8]. Due to their wide use the investigation of these compounds increase lately. First of all, their biological activity is investigated $[9,10]$.

The properties of the derivatives of 1,2,4triazoline-3-thione depend on acid-base processes and soacid-base equilibria are investigated in different media.It is known that the derivatives of 1,2,4-triazoline-3-thione in strong acid media behave as weak bases and the process of their protonation take place[11]. It is also known that the dissociation constant $\left(\mathrm{pK}_{\mathrm{BH}}{ }^{+}\right)$depends on the polarity of the molecule and on the intra-molecular 
and intermolecular forces [12]. The dissociation constants values of this kind compounds and its derivatives are important for studding the reaction mechanisms which take place in acidic media. Knowledge of the $\mathrm{pK}_{\mathrm{BH}}{ }^{+}$value of a substance is essential for various investigations in pharmacology and physiology, in structural, environmental, preparative, and analytical studies, and for industrial purposes [11]. On the other hand, acid-base equilibrias i.e. $\mathrm{pH}$ of the media defined the biological activity of such weak bases [13]. Karizky and Ress determined the values of the dissociation constants of 1,2,4-triazoline in acidic media $(p K=2.19)$ [14]. Furthermore, the dissociation constants values of protonated forms $\left(\mathrm{p} \mathrm{K}_{\mathrm{BH}}{ }^{+}\right)$of some derivatives of 1,2,4-triazoline determined in sulfuric acid media using the methods of UV spectroscopy could be found in the literature [15].
In our previous works the $\mathrm{pK}_{\mathrm{BH}}{ }^{+}$values of the compounds that we present in this paper were determined in sulfuric acid mediaand their dissociation constants in sodium hydroxide media $[16,17]$.Because of the influence of the acidity of the media on biological activity of these compounds we were interested to extend our investigations in other mineral acids. The compounds that were subject of our investigation: 4-butyl-5-octyl-2,4-dihydro-3H-1,2,4-triazoline-3-

thione(TTB), 4-allyl-5-octyl-2,4-dihydro-3H-1,2,4triazoline-3-thione (TTA), 4-phenyl-5-octyl-2,4dihydro-3H-1,2,4-triazoline-3-thione (TTP) were synthesized, for the first time by Ragenovicet al. [18]. Their structural formulas are shown below (Fig. 1).
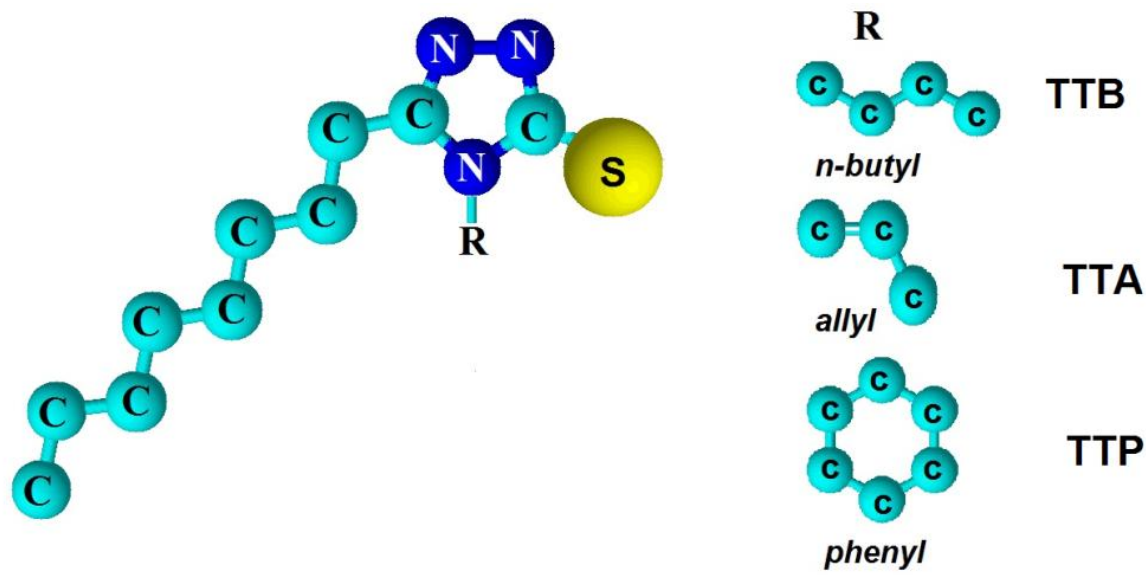

Figure 1. The structural formulas of TTB, TTA and TTP

Slika 1. Strukturne formule TTB, TTA i TTP

The aim of this work was to characterize qualitatively and quantitatively the processes that would take place in acid media using the method of UV spectroscopy. In order to investigate the influence of the strength of the acid and its anion on the protonation process perchloric, hydrochloric and phosphoric acid for protonation were used. Moreover, we investigated the electronic properties of studied triazole-3-thione compounds applying PM3 semiempirical method [19]. The values of total energies, heats of formation, dipole moments, ionization potential, energies of frontier molecular orbitals ( $E_{\mathrm{HOMO}}$ and $E_{\mathrm{LUMO}}$ ) and nucleophilicities were determined. In order to determine the possible center of protonation the full atomic charges and proton affinity values for the different nitrogen atoms and sulphur of the investigated thiones were calculated. The changes in the absorbance values with acidification of the solution were used for calculation of the dissociation constants of the protonated forms $\left(\mathrm{pK}_{\mathrm{BH}}{ }^{+}\right)$.

\section{MATERIALS AND METHODS}

\subsection{Theoretical investigation of protonation process - Quantum chemical investigation}

Semiemirical methods are usually used for calculation of different parameters for prediction of some properties and reaction in which organic compounds took place [20]. In this work, the determination of total energies, heats of formation, dipole moments, ionization potential, energies of frontier molecular orbitals ( $E_{\text {HOMO }}$ and $E_{\text {LUMO }}$ ), nucleophilicities, full atomic charges and proton affinity were performed with PM3 (Parametric Method 3) semiempirical SCF-MO method [19]. Theoretical calculations were carrying out at the restricted Hartree-Fock level (RHF) in the 
HYPERCHEM program. All the structures were optimized to a gradient norm of $<0.1$.

\subsection{Experimental investigation of protonation process}

Solutions and spectral measurements: The purity of the investigated compounds TTB, TTA and TTP was confirmed by quantitative elemental analysis and the recorded IR spectra [20]. All used chemicals (perchloric acid, hydrochloric acid, phosphoric acid and ethanol) were of analytical grade p.a.The stock solutions of the investigated compounds TTB, TTA and TTP were prepared in $96 \%$ ethanol with concentration of about $1.00 \cdot 10^{-3}$ $\mathrm{mol} / \mathrm{dm}^{3}$. The stability of these solutions was confirmed with the absorbance values measured in two months time. Three series of test solutions (with concentration of about $2.0 \cdot 10^{-5} \mathrm{~mol} / \mathrm{dm}^{3}$ were prepared for each investigated compound. The concentration of the compounds TTB, TTA and TTP in the test solution was kept constant, while the concentration of the mineral acids was gradually increased: from $1.0 \mathrm{~mol} / \mathrm{dm}^{3}$ to 11.0 $\mathrm{mol} / \mathrm{dm}^{3}$ for perchloric acid, from $1.0 \mathrm{~mol} / \mathrm{dm}^{3}$ to $12.0 \mathrm{~mol} / \mathrm{dm}^{3}$ for hydrochloric acid and between 1.0 $\mathrm{mol} / \mathrm{dm}^{3}$ and $14.0 \mathrm{~mol} / \mathrm{dm}^{3}$ for phosphoric acid. Parallely, the blanks were prepared with the same composition as the working solution, without the investigated compound. The ethanol content in the test solutions and in the blanks was $1 \%$. The spectrophotometric measurements were performed on a Varian Cary 50 spectrophotometer in the wavelength region from $190 \mathrm{~nm}$ to $360 \mathrm{~nm}$, immediately after preparation of the solutions at room temperature. For these measurements the quartz cell with $1 \mathrm{~cm}$ length was used.The maximum scan rate is $24000 \mathrm{~nm} / \mathrm{min}$ and resolution is $1.5 \mathrm{~nm}$. UV spectra were obtained with computer program Grams Version 4.10, while Excel program was applied for calculation of the dissociation constants of protonated form.

Calculation of $\mathrm{pK}_{\mathrm{BH}}{ }^{+}$values: The reaction of protonation of 1,2,4-triazole-3-thione in strong mineral acid can be presented using the following equation:

$$
B+H^{+} \rightarrow B H^{+}
$$

The equilibrium constant for this equation can be defined with the equation (2):

$$
p K_{B H}{ }^{+}=H_{0}+\log \left[c\left(B H^{+}\right) / c(B)\right]
$$

$H_{0}$ is the Hammett acidity function, which represents the acidity scale of the highly acidic media and is used for the determination of a weak base strength, $c\left(\mathrm{BH}^{+}\right)$is the concentration of the protonated form of the compound, $c(B)$ is the concentration of the unprotonated form of the compound. From the literature it is known that the $H_{0}$ acidity function depends on the class of the investigated compounds [21].Different values of $H_{0}$ are defined as $H_{\mathrm{x}}$, which describes most accurately the protonation process of different groups of compounds. For thiocarbonyl compounds, $H_{x}$ is noticed as $H_{\mathrm{T}}$ and its values are established for $10 \%-90 \%$ sulfuric acid aqueous solutions [22]. The $\mathrm{pK}_{\mathrm{BH}}{ }^{+}$values for thio-compounds were calculated by the equation (3) where $I$ is ionization ratio $\left(I=c\left(\mathrm{BH}^{+} / \mathrm{c}(\mathrm{B})\right)\right.$.

$$
p K_{B H^{+}}=\log l+H_{T}
$$

In the literature there are several methods for calculation of the dissociation constants of the protonated forms, but the most suitable is the "excessacidity" function method established by Cox and Yates [22]. Actually, the acidity function $X$ can be used for different compounds i.e. it is independent of the structure and the center of protonation of the investigated compounds [23]. According to this method the $\mathrm{p} \mathrm{K}_{\mathrm{BH}}{ }^{+}$values can be calculated using the equation (4):

$$
p K_{B H^{+}}{ }^{+}=\left[\log I-\log c H^{+}\right]-m^{*} X
$$

where, $I$ is a ratio between the concentration of the protonated and unprotonated form of the base (ionization ratio), $\mathrm{pK}_{\mathrm{BH}}{ }^{+}$is a dissociation constant, $m$ expresses the hydrogen-bonding salvation of the protonated basei.e. solvation parameter defined by Cox [24]. Its value when determined for thiocarbonyl compounds is in the range of $1.39 \pm$ 0.14 . $X$ is a function that represents the difference between the observed acidity and that which the system would have if it were ideal („excess acidity”) [25]. The values of this function were determined depending on sulfuric, perchloric and hydrochloric acid concentration $[26,27]$.

Additionally, the $\mathrm{pK}_{\mathrm{BH}}{ }^{+}$values of the investigated hydrazones were determined graphically as an intercept of the dependence of $\log /$ on $\mathrm{pH}$. When $c\left(\mathrm{BH}^{+}\right)=c(\mathrm{~B}), \log /=0$, and the graphically $\mathrm{p} K_{\mathrm{BH}}{ }^{+}$value is equal to the $H_{\mathrm{T}}$ value of solution [28]. In the case of "excess acidity" function method the dependence of $\log I-\log c\left(\mathrm{H}^{+}\right)$ vs $X$ is linear with intercept equal to the graphical value of the $\mathrm{p} K_{\mathrm{BH}}{ }^{+}$[29].

Method of Characteristic Vector Analysis (CVA): In order to obtain more precise results for $\mathrm{p} K_{\mathrm{BH}}{ }^{+}$values the influence of the solvent should be eliminated. There are several methods for this purpose [27], but one of the most commonly used methods for that purpose is Characteristic Vector 
Analysis (CVA) [30].This method is applicable in the analysis of spectroscopic data, to investigate problems dealing with protonation [31]. CVA is a method of separating independent factors for sets of multivariate response data [22]. The method can be used empirically for estimating the number of independent factors contributing to the total variation observes in a family of UV spectra. If $p$ independent factors are involved in generating the absorbance curve, the sample responses at each wavelength for a given concentration will be given by equation (5):

$$
\begin{aligned}
& A_{1}=A_{1}+C_{1} v_{11}+C_{2} v_{21}+\ldots \ldots \ldots+C_{p} v_{p 1} \\
& A_{2}=A_{2}+C_{1} v_{12}+C_{2} v_{22}+\ldots \ldots \ldots+C_{p} v_{p 2} \\
& A_{r}=A_{r}+C_{1} v_{1 r}+C_{2} v_{2 r}+\ldots \ldots \ldots+C_{p} v_{p r}
\end{aligned}
$$

The choice of $A$ is arbitrary and the mean values of the absorbance seem to be a convenient choice, while $v$ is characteristic vectors, and $c$ is weighting coefficients.

\section{RESULTS AND DISCUSSION}

\subsection{Theoretical investigation of protonation process}

First step in our study was theoretical investigation of protonation process of studied triazole-3-thione compounds applying PM3 semiempirical method in order to determine the possible center of protonation. The study of the electronic properties of triazoline-3-thione system (TT) is important because of the possible use of such information as an aid to the understanding of mode of action of these compounds as acid and base and co-coordinative species. Since, experimental determination of the protonation center of the triazole molecule in sulfuric acid was made [16], confirmation of protonation place in perchloric and hydrochloric acid media and theoretical calculation of protonation parameters of these compounds also appear important.

The investigated molecules contain hetero rings with aliphatic (TTB and TTA) and aromatic (TTP) substituents and interaction between them affect on their properties among which the proton affinity. On the other hand, the effect of tautomeric change on electronic properties can be evaluated by the theoretical investigation of the molecule. According the literature data, semiempirical methods have been used widely for the quantum chemical investigation of various heterocyclic compounds [32]. In this study, PM3 semiempirical method was used for quantum chemical investigation in order to investigate the electronic properties and to find out the protonation centres of TTB, TTA and TTP. Total energies $\left(E_{\mathrm{tot}}\right)$, heats of formation $\left(\Delta H_{f}^{0}\right)$, energies of frontier molecular orbitals ( $E_{\text {HOMO }}$ and $E_{\text {LUMO }}$ ), ionization potential (IP) and dipole moments $(\mu)$ of TTB, TTA and TTPwere calculated (Table 1). In fact, the stability of heterocyclic systems, such as triazole-3-thione depends on the conjugation between the heterocyclic ring, (in this case 1,2,4-triazole), aliphatic/aromatic rings and thion $(\mathrm{C}=\mathrm{S})$ /thiol ( $\mathrm{C}$ $\mathrm{SH})$ group in position 3 of the investigated compounds, and the interaction between them.

Table 1. Total energy $\left(E_{\text {tot }}\right)$, heats of formation $\left(\Delta H_{f}^{0}\right)$, energies of frontier molecular orbitals $\left(E_{\text {номо }}\right.$ and $\left.E_{\text {LUMO }}\right)$, nucleophilicities $\left(\eta^{a}\right)$, ionization potential (IP) and dipole moments $(\mu)$ for TTB, TTA and TTP

Tabela 1. Ukupna energija $\left(E_{\text {tot }}\right)$, toplote formiranja $\left(\Delta H f^{0}\right)$, energije graničnih molekularnih orbitala (EHOMO i ELUMO), nukleofilnost (a), potencijal jonizacije (IP) $i$ dipolni momenti (TTB, TTA $\mathrm{i}$ TTP)

\begin{tabular}{|l|c|c|c|}
\hline & TTB & TTA & TTP \\
\hline $\begin{array}{l}E_{\text {tot }} \\
{\left[\mathbf{k c a l} \cdot \mathrm{mol}^{-1}\right]}\end{array}$ & -63392.63 & -59206.51 & -67399.87 \\
\hline $\begin{array}{l}\Delta \boldsymbol{H}_{\mathrm{f}}^{0} \\
{\left[\mathbf{k c a l} \cdot \mathrm{mol}^{-1}\right]}\end{array}$ & -2.26 & 33.58 & 48.12 \\
\hline$E_{\text {Hомо }}[\mathrm{eV}]$ & -8.5581 & -8.5398 & -8.4922 \\
\hline$E_{\text {Lumo }}[\mathbf{e V}]$ & -0.5570 & -0.5333 & -0.5398 \\
\hline IP [eV] & 8.5581 & 8.5398 & 8.4922 \\
\hline$\eta^{\alpha}[\mathrm{eV}]$ & -8.0011 & -8.0065 & -7.9524 \\
\hline $\boldsymbol{\mu}[\mathrm{D}]$ & 5.374 & 5.261 & 5.617 \\
\hline
\end{tabular}

$\eta^{\alpha}=E_{\text {Hомо }}-E_{\text {LUMO }}, \mathrm{IP}=-E_{\text {Hомо }}$

The IP values of all compounds (Table 1) are relatively lower than literature reported IP for 1,2,4triazole. Namely, the experimental IP of 1,2,4triazole molecule was $10.00 \mathrm{eV}$ and calculated IP using PM3 and AM1 methods 10.39 and $10.27 \mathrm{eV}$, respectively [33]. The possible protonation pathways (monocations: N1, N2, N4 and S) for investigated thiones are described in Fig. 2.

In order to investigate the basicity of triazole-3thiones, prediction of possible protonation centers in molecule which contains various proton acceptor atoms is very significant. With that purpose, the atomic charges for TTB, TTA and TTP were determined and their values are listed in Table 2. 


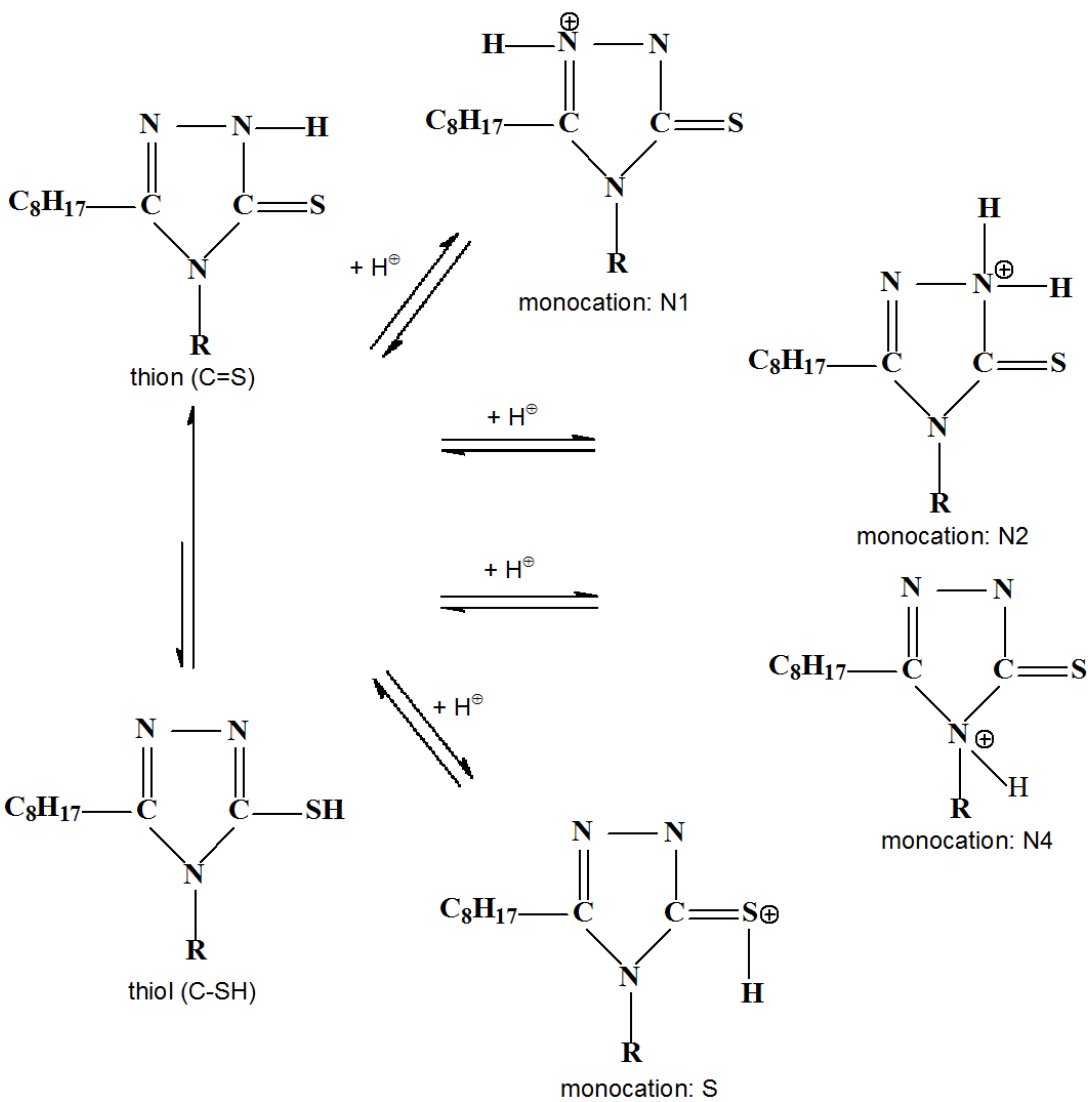

Figure 2. The possible site of protonation of tione form of triazoline-3-thiones

Slika 2. Moguće mesto protonacije tionovog oblika triazolina-3-tiona

Table 2. Atomic numeration and atomic charges of thione form for TTB, TTA and TTP

Tabela 2. Atomska numeracija $i$ atomske naboje tionovog oblika za TTB, TTA i TTP

\begin{tabular}{|c|c|c|c|c|c|}
\hline & \multicolumn{4}{|c|}{ Atomic charge } & Thione form \\
\hline Atom & N1 & N2 & N4 & $\mathbf{s}$ & \\
\hline TTB & -0.200 & 0.239 & 0.179 & -0.308 & $\mathrm{C}_{8} \mathrm{H}_{17-}$ \\
\hline TTA & -0.201 & 0.241 & 0.227 & -0.313 & \\
\hline TTP & -0.199 & 0.181 & 0.250 & -0.298 & $\mathbf{R}$ \\
\hline
\end{tabular}

In accordance with the negative charge distribution on $\mathrm{S}$ atom for all investigated compounds this atom was with the largest electron density in the molecule (Table 2). For this reason, the $S$ was predicted to be the main site of the molecule for the electrophlic attack of hydrogen. Next step for determination of the exact protonation center of investigated thiones was calculation of the proton affinities for different atoms in the thione molecule. Hence, the stable conformations for the monocations formed as a result of protonation of different atoms in triazoline-3-thione molecule such as $\mathrm{N} 1, \mathrm{~N} 2, \mathrm{~N} 4$ and $\mathrm{S}$ were determined with full geometry optimization using the heats of formation $\left(\Delta H_{\mathrm{f}}^{0}\right)$ values obtained with $\mathrm{PM} 3$ semiempirical method (Table 3 ). The proton affinity values were calculated using the equation (6):

$$
P A=367.2+\Delta H_{f}^{0}(B)+\Delta H_{f}^{0}\left(B H^{+}\right)
$$

where, PA is proton affinity, $\Delta H_{\mathrm{f}}^{0}(\mathrm{TT})$ is the heat of formation for the TT molecule, $\Delta H_{\mathrm{f}}^{0}\left(\mathrm{TTH}^{+}\right)$is the heat of formation for the cation and $367.2 \mathrm{kcal} \mathrm{mol}^{-1}$ is the heat of formation for the proton $\left(\mathrm{H}^{+}\right)$. 
Table 3. Total energies $\left(E_{\text {tot }}\right)$, heats of formation $\left(\Delta H_{f}^{0}\right)$ and dipole moments $(\mu)$ of the protonated forms of triazoline-3-thiones

Tabela 3. Ukupne energije $\left(E_{t o t}\right)$, toplote formiranja $\left(\left(\Delta H f^{0}\right)\right.$ i dipolni momenti $(\mu)$ ?@>B>=iranih oblika triazolin-3tiona

\begin{tabular}{|c|c|c|c|c|}
\hline \multicolumn{5}{|c|}{ TTB } \\
\hline & N1 & N2 & N4 & $\mathbf{S}$ \\
\hline$E_{\text {tot }}[\mathrm{kcal} / \mathrm{mol}]$ & -63574.68 & -63564.88 & -63553.26 & -63598.19 \\
\hline$\Delta \boldsymbol{H}_{f}^{0}[\mathrm{kcal} / \mathrm{mol}]$ & 169.27 & 179.07 & 190.69 & 145.76 \\
\hline$\mu[\mathrm{D}]$ & 7.410 & 11.453 & 10.105 & 13.134 \\
\hline PA & 195.67 & 185.87 & 174.25 & 219.18 \\
\hline \multicolumn{5}{|c|}{ TTA } \\
\hline & N1 & N2 & N4 & $\mathrm{S}$ \\
\hline$E_{\text {tot }}[\mathrm{kcal} / \mathrm{mol}]$ & -59388.90 & -59379.50 & -59367.80 & -59413.01 \\
\hline$\Delta \boldsymbol{H}_{f}^{0}[\mathrm{kcal} / \mathrm{mol}]$ & 204.74 & 214.17 & 225.87 & 180.66 \\
\hline$\mu[\mathrm{D}]$ & 8.345 & 12.636 & 11.991 & 13.404 \\
\hline PA & 196.04 & 186.61 & 174.91 & 220.12 \\
\hline \multicolumn{5}{|c|}{ TTP } \\
\hline & N1 & N2 & N4 & $\mathbf{S}$ \\
\hline$E_{\text {tot }}[\mathrm{kcal} / \mathrm{mol}]$ & -67584.82 & -67574.88 & -67567.27 & -67610.72 \\
\hline$\Delta \boldsymbol{H}_{f}^{0}[\mathrm{kcal} / \mathrm{mol}]$ & 216.74 & 226.68 & 234.29 & 190.84 \\
\hline$\mu[\mathrm{D}]$ & 7.722 & 11.239 & 8.935 & 11.962 \\
\hline PA & 198.58 & 188.64 & 181.03 & 224.48 \\
\hline
\end{tabular}

Comparing the result shown in Table 3 it can be noticed that the PA values of $S$ atomare higher than PA values of the nitrogens for all investigated compounds. In other words, the electrophilic attack of the proton on the $S$ atom is easier than the nitrogen atoms. Hence, the most probably place of protonation in the molecule of 1,2,4-triazoline-3thioneis the sulfur in the thiourea fragment, as it was the case in sulfuric acid media [16]. Taking into account the previous results, the protonation process of the investigated thione could be illustrated by the Fig.3.<smiles>[R]n1c([CH2])n[nH]c1=S</smiles><smiles>[CH+]C[CH+]O</smiles><smiles>[R]n1c([15CH2])n[nH]c1=[SH+]</smiles>

Figure 3. Protonation reaction of the 1,2,4-triazoline-3-thiones

Slika 3.Reakcija protonacije 1,2,4-triazolina-3-tiona

\subsection{Experimental investigation of protonation process}

After theoretical determination of the possible center of protonation in triazole-3-thione molecule, second step was experimental conformation of theoretically assumed protonation processes. The experimental UV spectra of the investigated thiones: 4-butyl-5-octyl-2,4-dihydro-3H-1,2,4triazoline-3-thione(TTB), 4-allyl-5-octyl-2,4-dihydro-
3H-1,2,4-triazoline-3-thione (TTA), 4-phenyl-5octyl-2,4-dihydro-3H-1,2,4-triazoline-3-thione (TTP) in perchloric acid media with concentration from 1.0 $\mathrm{mol} / \mathrm{dm}^{3}$ (spectrum 1) to $11.0 \mathrm{~mol} / \mathrm{dm}^{3}$ (spectrum 10) are presented in Fig. 4 (a-c). The UV spectra recorded in hydrochloric and phosphoric acid media were similar to those obtained in perchloric acid media, because of that they are not presented here. 

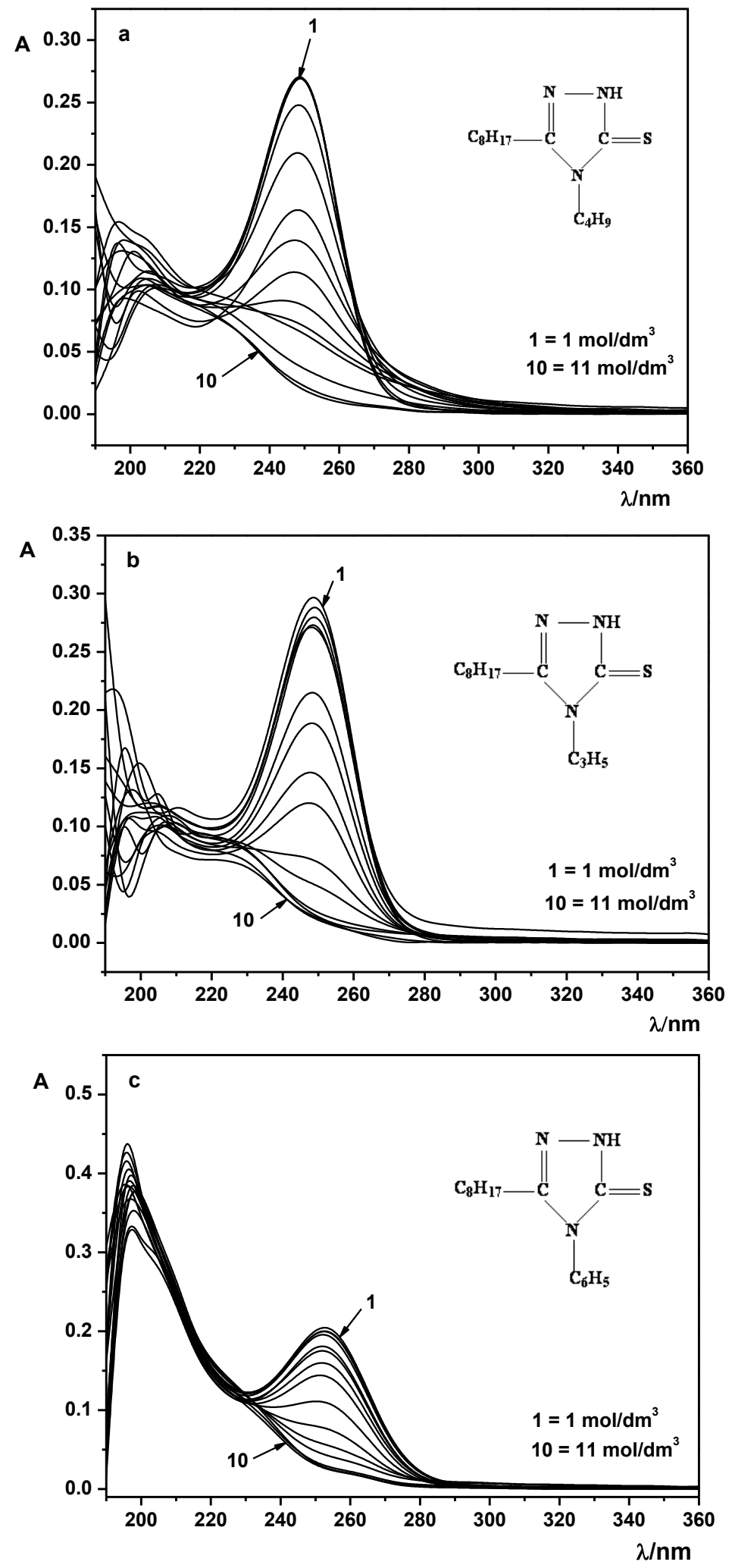

Figure4. UV spectra of a) TTB, b) TTA and c) TTP $\left(c=2.0 \cdot 10^{-5} \mathrm{~mol} / \mathrm{dm}^{3}\right)$ in perchloric acidmedia (from $1.0 \mathrm{~mol} / \mathrm{dm}^{3}$ (spectrum 1)to $11.0 \mathrm{~mol}^{2} \mathrm{dm}^{3}$ (spectrum 10))

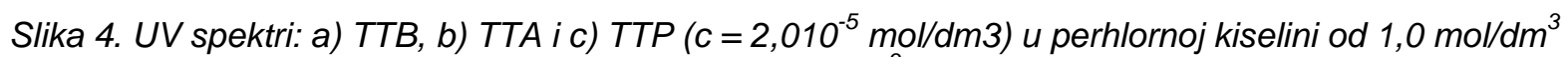
(spektar 1) do 11,0 mol/dm (spektar 10) 
From the Fig.4(a-c) it could be noticed that in the spectra of the investigated compounds appear two bands. The first band that appears around 200 $\mathrm{nm}$ is less intensive for thiones TTB and TTA, and more intensive for thione TTP. This band is probably a result of $\pi \rightarrow \pi^{\star}$ electron transitions in the benzene ring. The second intensive band appears at around $250 \mathrm{~nm}$ for thiones TTB and TTA and around $255 \mathrm{~nm}$ for thione TTP. The presence of absorption maximum at about $250 \mathrm{~nm}$ in the UV spectra of triazoline-3-thiones in neutral media was expected as a result of electron transition in the 1,2,4-triazoline-3-thione ring [34]. As in the case of other heterocyclic thiones, it is possible to consider that the 1,2,4-triazoline-3-thiones may exist in thion-thiol tautomeric forms (TT) [35]. The literature data indicated that the thione form is the predominant tautomer. The presence of the maximum in the UV spectra at around $250 \mathrm{~nm}$ indicated that the thione structure dominates in the polar solvents. In addition to the UV data, the IR and NMR data of thiones support the thion form in solid state and in solutions [36]. The changes in the second band $(250 \mathrm{~nm})$ in the acid medium were interesting for our further investigations. Namely, when the concentration of the perchloric acid increase between $1.0 \mathrm{~mol} / \mathrm{dm}^{3}$ and $11.0 \mathrm{~mol} / \mathrm{dm}^{3}$ the intensity of this band decrease, but its position does not change (Fig.4(a-c)). The same situation was noticed in the hydrochloric and phosphoric acid media. When the concentration of perchloric acid was up to $9.0 \mathrm{~mol} / \mathrm{dm}^{3}$ (in hydrochloric acid up to $7.0 \mathrm{~mol} / \mathrm{dm}^{3}$ and in phosphoric acid up to 10.0 $\mathrm{mol} / \mathrm{dm}^{3}$ ) the band almost disappeared. The observed changes in the experimental UV spectra show, as it was expected, that the behavior of the investigated thiones in used mineral acids is analogous to that in sulfuric acid medium [16].

From the Fig.4(a-c), it could be seen that the existence of the isosbestic point is expected at wavelength about $210 \mathrm{~nm}$. In order to eliminate the effect of the solvent and to determine the precise position of the isosbestic point the experimental UV spectra were reconstructed [30]. For example, the reconstructed UV spectra of the compound TTB in perchloric acid media are shown in the Fig. 5.

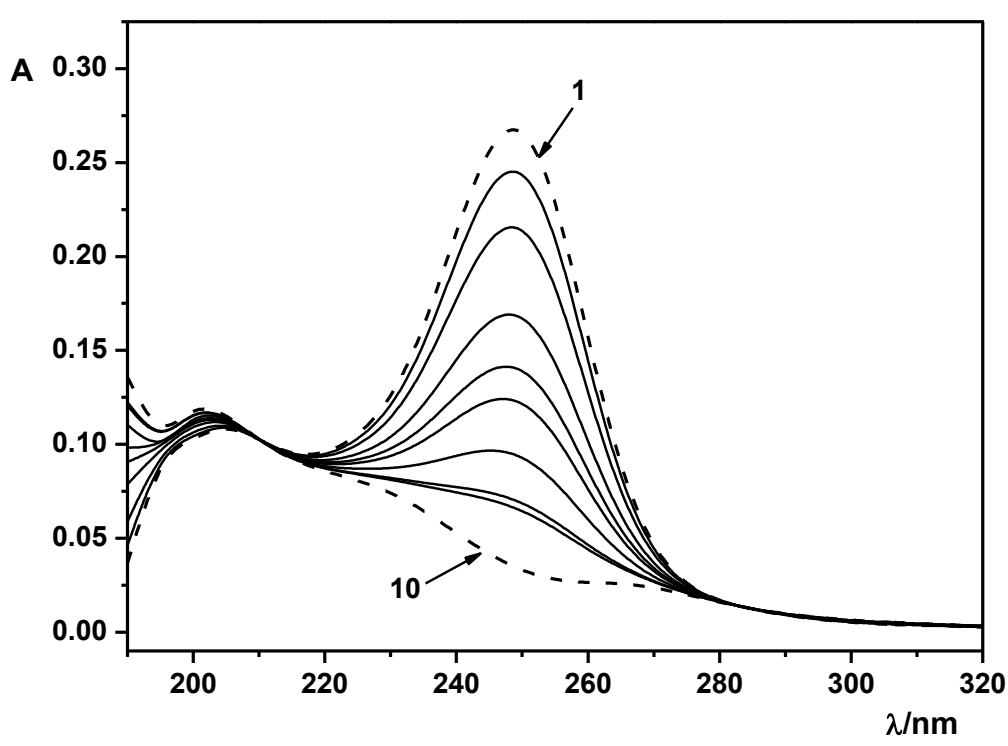

Figure 5. Reconstructed UV spectra of TTB $\left(2.0 \cdot 10^{-5} \mathrm{~mol} / \mathrm{dm}^{3}\right)$ in perchloricacidmedia $\left(c=1.0 \mathrm{~mol} / \mathrm{dm}^{3}\right.$ $11.0 \mathrm{~mol} / \mathrm{dm}^{3}$ )

Slika 5. Rekonstruisani UV spektri TTB (2,0 10-5mol/dm $\left.{ }^{3}\right)$ u perhlornoj kiselini (c = 1,0 mol/ $\mathrm{dm}^{3}-11,0$ $\mathrm{mol} / \mathrm{dm}^{3}$ )

The existence of the isosbestic point in the reconstructed spectra for all compounds suggests that probably two forms exist in the system, the compound in its protonated and unprotonated form, respectively. That indicates that the protonation process occurs in one step. This supposition can be confirmed with the appearance of the $A_{\lambda} v s$ concentration of the mineral acid („S" curve). The "S" curves of the compound TTP in perchloric, hydrochloric and phosphoric acid mediumare presentedin the Fig. 6 . 


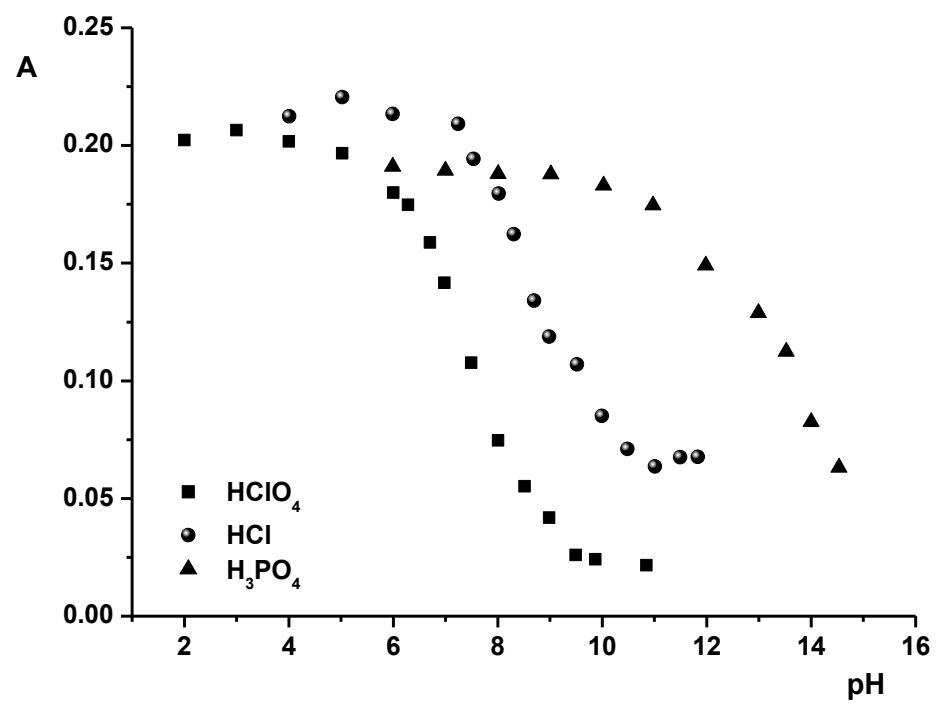

Figure 6. Theabsorbancevalues $(\lambda=255 \mathrm{~nm}$ ) as a function of perchloric (curve $\mathbf{-})$, hydrochloric (curve $\mathbf{\Delta}$ ) and phosphoric(curve $\bullet$ ) acidconcentrationfor TTP $\left(c=2.0 \cdot 10^{-5} \mathrm{~mol} / \mathrm{dm}^{3}\right)$

Slika 6. Vrednosti apsorpcije $(\lambda=255 \mathrm{~nm})$ kao funkcija koncentracije perhlorne (krivulja $\mathbf{n})$, hlorovodonične (krivulja $\Delta$ ) i fosforne (krivulja •) kiseline za TTP $\left(c=2,010^{-5} \mathrm{~mol} / \mathrm{dm}^{3}\right)$

The existence of one plateau on the sigmoidal curve additionally indicates that the protonation process take place in one step. One step was noticed in the "S" curves for the compounds TTB and TTA in all used mineral acids and in the "S" curve for the compound TTP in hydrochloric acid media (the plots are not shown). In phosphoric acid media the "S" curve did not have final part (Fig. 6, curve $\bullet$ ) which means that the protonation process in this acid is not finished even when its concentration is to the highest degree. The same conclusion was observed for the thiones TTB and TTA. From the presented "S" curves it can be noticed that the protonation process of the investigated thiones TTB, TTA and TTP in perchloric acid media is carried out in the concentration range from $5.0 \mathrm{~mol} / \mathrm{dm}^{3}$ to 9.0 $\mathrm{mol} / \mathrm{dm}^{3}$ (Fig. 6 (curve a)). Unprotonated forms of the investigated compounds exist below perchloric acid concentration of $5.0 \mathrm{~mol} / \mathrm{dm}^{3}$, while above 9.0 $\mathrm{mol} / \mathrm{dm}^{3}$ only the protonated forms are present. In hydrochloric acid media the investigated compounds are protonated in the concentration range from $7.0 \mathrm{~mol} / \mathrm{dm}^{3}$ to $11.0 \mathrm{~mol} / \mathrm{dm}^{3}$, while in phosphoric acid media the protonation process starts at about $10 \mathrm{~mol} / \mathrm{dm}^{3}$ (Fig. 6). The obtained results show that the investigated thiones in investigated mineral acids behave as bases and they are protonated at high mineral acid concentration. The same conclusion was performed in our previous investigations for these thiones in sulfuric acid media [16].

\subsection{Determination of the dissociation constants of 1,2,4-triazoline-3-thiones}

The calculations of the dissociation constants of protonated forms $\left(\mathrm{p} K_{\mathrm{BH}}{ }^{+}\right)$of investigated compounds were made from the absorbance data in perchloric and hydrochloric acid media. It was not possible the protonation process to characterize quantitatively in phosphoric acid media because the protonation reaction was not completed when the highest concentration of this acid was used.The $\mathrm{p} K_{\mathrm{BH}}{ }^{+}$values were calculated using the values of the absorbance measured at four selected wavelengths (experimental and reconstructed spectra): $230 \mathrm{~nm}, 240 \mathrm{~nm}, 250 \mathrm{~nm}$ and $260 \mathrm{~nm}$ for the compounds TTB and TTA, and $240 \mathrm{~nm}, 250 \mathrm{~nm}, 260 \mathrm{~nm}$ and $270 \mathrm{~nm}$ for the compound TTP, in perchloric acid media. In hydrochloric acid media following wavelengths: $230 \mathrm{~nm}, 240 \mathrm{~nm}, 250 \mathrm{~nm}$ and $260 \mathrm{~nm}$ were selected for all investigated compound.The dissociation constants in mineral acid media were evaluated using the ionization ratio $\left(I=\mathrm{C}_{\mathrm{BH}}{ }^{+} / C_{\mathrm{B}}\right)$ values determined spectrophotometricaly from the absorbance values (experimental and reconstructed spectra) measured at four wavelengths and from the values of the molar absorption coefficients determined at the same wavelengths, in accordance with Beer's law. The molar absorption coefficient values were determined by measuring the absorbance of investigated thiones at the concentration $1.6 \cdot 10^{-5}$ $\mathrm{mol} / \mathrm{dm}^{3}, 2.0 \cdot 10^{-5} \mathrm{~mol} / \mathrm{dm}^{3}$ and $2.4 \cdot 10^{-5} \mathrm{~mol} / \mathrm{dm}^{3}$ at the same selected wavelengths. The 
measurements for unprotonated form of the investigated compounds were performed at mineral acid (perchloric and hydrochloric) concentration of
$2 \mathrm{~mol} / \mathrm{dm}^{3}$, while for protonated form at about 11 $\mathrm{mol} / \mathrm{dm}^{3}$ (Table 4).

Table 4. The molar absorption coefficient values of protonated $\left(\mathrm{BH}^{+}\right)$and unprotonated forms $(\mathrm{B})$ for the compounds TTB, TTA and TTP in $\mathrm{HClO}_{4}$ and $\mathrm{HCl}$

Tabela 4. Molarne vrednosti koeficijenta apsorpcije protonirani $\left(B^{+}\right)$i neprotonirani oblici $(B)$ za jedinjenja TTB, TTA i TTP u $\mathrm{HClO}_{4}$ i $\mathrm{HCl}$

\begin{tabular}{|c|c|c|c|c|c|c|c|}
\hline \multicolumn{4}{|c|}{ Compound } & ${ }^{*} \varepsilon(230 \mathrm{~nm})$ & $\varepsilon(240 \mathrm{~nm})$ & $\varepsilon(250 \mathrm{~nm})$ & $\varepsilon(260 \mathrm{~nm})$ \\
\hline \multirow{8}{*}{$\stackrel{n}{E}$} & \multirow{4}{*}{$\frac{\text { 은 }}{\text { บ }}$} & \multirow{2}{*}{ I } & $\varepsilon(\mathrm{B})$ & 65.70 & 113.61 & 145.15 & 74.86 \\
\hline & & & $\varepsilon\left(\mathrm{BH}^{+}\right)$ & 37.69 & 20.95 & 8.61 & 4.39 \\
\hline & & \multirow{2}{*}{ II } & $\varepsilon(\mathrm{B})$ & 65.70 & 113.65 & 145.20 & 74.92 \\
\hline & & & $\varepsilon\left(\mathrm{BH}^{+}\right)$ & 37.67 & 20.98 & 8.69 & 4.42 \\
\hline & \multirow{4}{*}{ ত্ } & \multirow{2}{*}{ I } & $\varepsilon(\mathrm{B})$ & 73.05 & 106.42 & 141.91 & 90.14 \\
\hline & & & $\varepsilon\left(\mathrm{BH}^{+}\right)$ & 46.73 & 32.78 & 19.39 & 11.37 \\
\hline & & \multirow{2}{*}{ II } & $\varepsilon(\mathrm{B})$ & 73.03 & 106.52 & 142.01 & 90.17 \\
\hline & & & $\varepsilon\left(\mathrm{BH}^{+}\right)$ & 46.77 & 32.79 & 19.42 & 11.43 \\
\hline \multirow{9}{*}{ E } & & & & $\varepsilon(230 \mathrm{~nm})$ & $\varepsilon(240 \mathrm{~nm})$ & $\varepsilon(250 \mathrm{~nm})$ & $\varepsilon(260 \mathrm{~nm})$ \\
\hline & \multirow{4}{*}{$\begin{array}{l}\frac{0}{0} \\
\text { ㅁ }\end{array}$} & \multirow{2}{*}{1} & $\varepsilon(\mathrm{B})$ & 60.85 & 113.14 & 151.83 & 82.39 \\
\hline & & & $\varepsilon\left(\mathrm{BH}^{+}\right)$ & 36.00 & 23.12 & 11.68 & 6.58 \\
\hline & & \multirow{2}{*}{ II } & $\varepsilon(\mathrm{B})$ & 60.84 & 113.11 & 151.80 & 82.38 \\
\hline & & & $\varepsilon\left(\mathrm{BH}^{+}\right)$ & 36.09 & 23.11 & 13.52 & 7.84 \\
\hline & \multirow{4}{*}{ ত্য } & \multirow{2}{*}{ I } & $\varepsilon(\mathrm{B})$ & 56.33 & 92.97 & 129.89 & 74.48 \\
\hline & & & $\varepsilon\left(\mathrm{BH}^{+}\right)$ & 42.72 & 35.17 & 24.45 & 15.01 \\
\hline & & \multirow{2}{*}{ II } & $\varepsilon(\mathrm{B})$ & 56.30 & 92.95 & 129.87 & 74.45 \\
\hline & & & $\varepsilon\left(\mathrm{BH}^{+}\right)$ & 42.72 & 35.19 & 24.43 & 13.16 \\
\hline \multirow{9}{*}{ 足 } & & & & $\varepsilon(240 \mathrm{~nm})$ & $\varepsilon(250 \mathrm{~nm})$ & $\varepsilon(260 \mathrm{~nm})$ & $\varepsilon(270 \mathrm{~nm})$ \\
\hline & \multirow{4}{*}{$\frac{\stackrel{0}{+}}{\text { ำ }}$} & \multirow{2}{*}{ I } & $\varepsilon(\mathrm{B})$ & 71.90 & 98.85 & 84.38 & 37.78 \\
\hline & & & $\varepsilon\left(\mathrm{BH}^{+}\right)$ & 32.43 & 16.62 & 11.68 & 7.55 \\
\hline & & \multirow{2}{*}{ II } & $\varepsilon(\mathrm{B})$ & 71.94 & 98.93 & 84.43 & 37.77 \\
\hline & & & $\varepsilon\left(\mathrm{BH}^{+}\right)$ & 33.11 & 17.14 & 12.32 & 8.21 \\
\hline & \multirow{4}{*}{ ত্工 } & \multirow{2}{*}{1} & $\varepsilon(\mathrm{B})$ & 86.58 & 78.90 & 108.95 & 97.02 \\
\hline & & & $\varepsilon\left(\mathrm{BH}^{+}\right)$ & 61.47 & 45.56 & 27.16 & 18.08 \\
\hline & & \multirow{2}{*}{ II } & $\varepsilon(\mathrm{B})$ & 86.70 & 79.06 & 109.10 & 99.17 \\
\hline & & & $\varepsilon\left(\mathrm{BH}^{+}\right)$ & 61.42 & 45.52 & 28.84 & 21.84 \\
\hline
\end{tabular}

I - experimental spectra; II - reconstructed spectra;

As we mentioned before, the,excess acidity” function method was applied for calculation of the $\mathrm{pK}_{\mathrm{BH}}{ }^{+}$values (Eq. 5). The values of the acidity function $X v s$ perchloric and hydrochloric acid were used from the literature [26]. The $\mathrm{pK}_{\mathrm{BH}}{ }^{+}$values were also determined graphically. As it is mentioned in the materials and methods the dependence of log /$\log c\left(\mathrm{H}^{+}\right)$vs $X$ is linear with intercept equal to the graphical value of the $\mathrm{pK}_{\mathrm{BH}}{ }^{+}$[29]. The dissociation constants of protonated form determined numerically and graphically from the absorbance values of the experimental and the reconstructed spectra for thiones TTB, TTA and TTP at the selected wavelengths in perchloric and hydrochloric acid media are given in Table 4 . The values of the solvation parameter $\left(m^{*}\right)$, coefficient of determination $\left(R^{2}\right)$, standard deviation (SD), relative standard deviation (RSD) and the interval where the obtained results are placed with the confidence level of $95 \%$ are calculated, too (Table $5)$. 
Table 5. $\mathrm{pK}_{\mathrm{BH}}{ }^{+}$values for the compounds TTB, TTA and TTP in perchloric and hydrochloric acid media (experimental and reconstructed spectra)

Tabela 5. $\mathrm{PK}_{\mathrm{BH}}{ }^{+}$vrednosti za jedinjenja TTB, TTA i TTP u perhlorne i hlorovodonične kiseline (eksperimentalni $i$ rekonstruisani spektar)

\begin{tabular}{|c|c|c|c|c|c|c|c|c|}
\hline & & \multicolumn{4}{|c|}{ Numerically } & \multicolumn{3}{|c|}{ Graphycally } \\
\hline \multicolumn{2}{|c|}{ Compound } & $\mathrm{p} K_{\mathrm{BH}}{ }^{+}$ & $m^{*}$ & SD & RSD & $\mathrm{p} K_{\mathrm{BH}}{ }^{+}$ & $R^{2}$ & $\mathbf{n}$ \\
\hline \multirow{6}{*}{$\frac{\text { 오 }}{\text { ㅁ }}$} & \multirow{2}{*}{ TTB } & $-3.08 \pm 0.04^{1}$ & 1.02 & 0.06 & 2.03 & $-3.08^{1}$ & 0.994 & 8 \\
\hline & & $-3.07 \pm 0.03^{2}$ & 1.04 & 0.05 & 1.54 & $-3.07^{2}$ & 0.996 & 8 \\
\hline & \multirow{2}{*}{ TTA } & $-3.07 \pm 0.03^{1}$ & 1.08 & 0.04 & 1.46 & $-3.07^{1}$ & 0.996 & 9 \\
\hline & & $-3.04 \pm 0.01^{2}$ & 1.09 & 0.02 & 0.56 & $-3.04^{2}$ & 0.998 & 9 \\
\hline & \multirow{2}{*}{ TTP } & $-3.18 \pm 0.04^{1}$ & 1.06 & 0.06 & 2.09 & $-3.19^{1}$ & 0.992 & 9 \\
\hline & & $-3.16 \pm 0.04^{2}$ & 1.05 & 0.07 & 2.16 & $-3.16^{2}$ & 0.992 & 9 \\
\hline \multirow{6}{*}{ 오 } & \multirow{2}{*}{ TTB } & $-3.38 \pm 0.04^{1}$ & 0.95 & 0.07 & 2.05 & $-3.38^{1}$ & 0.968 & 10 \\
\hline & & $-3.36 \pm 0.04^{2}$ & 0.94 & 0.06 & 1.85 & $-3.38^{2}$ & 0.974 & 10 \\
\hline & \multirow{2}{*}{ TTA } & $-3.39 \pm 0.04^{1}$ & 0.95 & 0.06 & 1.93 & $-3.39^{1}$ & 0.972 & 11 \\
\hline & & $-3.29 \pm 0.03^{2}$ & 0.89 & 0.05 & 1.40 & $-3.31^{2}$ & 0.984 & 11 \\
\hline & \multirow{2}{*}{ TTP } & $-3.50 \pm 0.03^{1}$ & 0.96 & 0.04 & 1.29 & $-3.48^{1}$ & 0.986 & 10 \\
\hline & & $-3.40 \pm 0.03^{2}$ & 0.93 & 0.05 & 1.51 & $-3.42^{2}$ & 0.982 & 10 \\
\hline
\end{tabular}

${ }^{1}$ experimental spectra, ${ }^{2}$ reconstructed spectra, n-number of measurements

The dissociation constants of the protonated forms of the compounds calculated from the absorbance values of the experimental spectra have lower values compared to those calculated from the absorbance values of the reconstructed spectra. These changes are probably due to the influence of the solvent that was confirmed with our previous investigations [16].The compound TTP (Table 5) has more negative $\mathrm{p} K_{\mathrm{BH}}{ }^{+}$values $\left(\mathrm{pK}_{\mathrm{BH}}{ }^{+}=\right.$ -3.18) than the compounds TTB $\left(\mathrm{pK}_{\mathrm{BH}}{ }^{+}=-3.0\right)$ and TTA $\left(\mathrm{pK}_{\mathrm{BH}}{ }^{+}=-3.08\right)$. This is probably as a result of the influence of the phenyl group in position 4 of the compound TTP. Hence, the compound TTP is weaker base compared to the compounds that have alkyl group in this position. It has to be noticed that the standard deviation values (SD) and the values of the relative standard deviation (RSD) are lower when the calculation were made from the absorbance values from the reconstructed spectra (Tables 5). It suggests that the $\mathrm{pK}_{\mathrm{BH}}{ }^{+}$values calculated from the reconstructed spectra are more precise, as we expected. Furthermore, there was a good agreement between the $\mathrm{pK}_{\mathrm{BH}}{ }^{+}$values of investigated thiones and those of similar class of compounds $[15,37]$. The $\mathrm{pK}_{\mathrm{BH}}{ }^{+}$values determined from the absorbance values of the reconstructed spectra in perchloric and hydrochloric acid media obtained according "excess acidity" function method are given in Table 6 . For comparison, in the Table 6 the $\mathrm{pK}_{\mathrm{BH}}{ }^{+}$values in sulfuric acid medium are also presented.
Table 6. $\mathrm{pK}_{\mathrm{BH}}{ }^{+}$values of the compounds TTB, TTA and TTP perchloric and hydrochloric acid media (reconstructed spectra) and in sulfuric acid

Tabela 6. $\mathrm{pK}_{\mathrm{BH}}{ }^{+}$vrednosti jedinjenja TTB, TTA i TTP u perhlorne $i$ hlorovodonične kiseline (rekonstruisani spektar) i sumporne kiseline

\begin{tabular}{|c|c|c|c|c|}
\hline & Compound & TTB & TTA & TTP \\
\hline \multirow{3}{*}{$\mathbf{p K}_{\mathrm{BH}}{ }^{+}$} & $\mathrm{HClO}_{4}$ & -3.07 & -3.04 & -3.16 \\
\cline { 2 - 5 } & $\mathbf{H C l}$ & -3.36 & -3.29 & -3.40 \\
\cline { 2 - 5 } & $\mathbf{H}_{\mathbf{2}} \mathrm{SO}_{4}$ & -3.00 & -3.11 & -3.18 \\
\hline
\end{tabular}

From the results shown in Table 6 it could be noticed that the $\mathrm{p} \mathrm{K}_{\mathrm{BH}}{ }^{+}$values in hydrochloric acid media are more negative than the $\mathrm{pK}_{\mathrm{BH}}{ }^{+}$values in sulfuric acid media and in perchloric acid media [20]. In spite of this, the dissociation constants determined in sulfuric acid media have lower negative values compared to the $\mathrm{pK}_{\mathrm{BH}}{ }^{+}$values determined in perchloric acid media. The exception is the compound TTB. This is expected because the hydrochloric acid is the weakest protondonor, while the perchloric acid is strongest one. Namely, it is well known that the strength of the acid and its anion influence on the $\mathrm{pK}_{\mathrm{BH}}{ }^{+}$values [30]. According our previous investigation in sulfuric acid media, the protonation process probably occurs onthe thiourea fragment of the 1,2,4-triazoline-3-thione ring [16]. This was confirmed by the value of theslope $m^{*}$ which is characteristic for the protonationof sulfur. 


\section{CONCLUSION}

The protonation processes of 1,2,4-triazoline-3thionesin perchloric, hydrochloric and phosphoric acid media was followed using UV spectroscopy. The changes of the absorbance values with acidity of the medium demonstrated that the protonation process in perchloric and hydrochloric acid occurs in one step, while in phosphoric acid protonation reaction did not finish. Using the absorbance data from the experimental and reconstructed UV spectra, the values of the dissociation constants of protonated form $\left(\mathrm{pK}_{\mathrm{BH}}{ }^{+}\right)$were calculated numerically and graphically. The separation of the protonation effects from the medium effects in the UV spectra was carried out by CVA method. The $S D$ values and the RSD values suggested that the $\mathrm{pK}_{\mathrm{BH}}{ }^{+}$values calculated from the reconstructed spectra were more precise compared to those calculated from experimental spectra. As a result of the influence of the phenyl group the compound TTP has more negative $\mathrm{pK}_{\mathrm{BH}}{ }^{+}$values i.e. it is weaker base compared to the compounds TTB and TTA.The obtained results in different mineral acid media suggest that the strength of the acid and its anion influence on the $\mathrm{pK}_{\mathrm{BH}}{ }^{+}$values of weak organic bases. A PM3 semiempirical method was applied in order to predict the protonation site. Based on the obtained proton affinity values and negative charge distribution on atoms, the sulfur atom was predicted to be the main site of the molecule for the electrophlic attack of hydrogen.

\section{REFERENCES}

[1] C.Temple, J.A.Montgomery (2008) The Chemistry of Heterocyclic Compounds, Triazoles 1, 2, 4 (Chemistry of Heterocyclic Compounds: A Series of Monographs), John Wiley \& Sons, Inc., Hoboken, NJ, USA.

[2] T.Pospieszny, H.Koenig, I.Kowalczyk, B.Brycki (2014) Synthesis, Spectroscopic and Theoretical Studies of New Quasi-Podands from Bile Acid Derivatives Linked by 1,2,3-Triazole Rings, Molecules, 19, 2557-2570.

[3] T.Pospieszny, I.Małecka, Z.Paryzek (2012) Synthesis and spectroscopic studies of new bile acid derivatives linked by a 1,2,3-triazole ring, Tetrahedron Letters, 53, 301-305.

[4] A.Lauria, R.Delisi, F.Mingoia, A.Terenzi, A. Martorana, G.Barone, A.M.Almerico (2014) 1,2,3Triazole in Heterocyclic Compounds, Endowed with Biological Activity, through 1,3-Dipolar Cycloadditions, European Journal of Organic Chemistry, 16, 3289-3306.

[5] K.C.Ragenović, V.Dimova, V.Kakurinov, D.M. Gabor, A.Buzarovska (2001) Synthesis and antibacterial and antifungal activity of 4 -substituted5-aryl-1,2,4-triazole, Moleculs, 6, 815-824.

[6] R.J.Ekiert, J.Krzek, P.Talik (2010) Chromatographic and electrophoretic techniques used in the analysis of triazole antifungal agents-a review, Talanta, 82(4), 1090-1100.
[7] R.Tang, L.Jin, C.Mou, J.Yin, S.Bai, D.Hu, J.Wu, S.Yang, B.Song (2013) Synthesis, antifungal and antibacterial activity for novel amide derivatives containing a triazole moiety, Chemistry Central Journal, 7(30), 1-7.

[8] A.Cetin, I.H.Geçibesler (2015) Evaluation as antioxidant agents of 1,2,4-triazole derivatives: effects of essential functional groups, Journal of Applied Pharmaceutical Science, 5(06), 120-126.

[9] J.K.Sahu, S.Ganguly, A.Kaushik (2014) Synthesis and antimicrobial activity of some novel fused heterocyclic 1,2,4-triazolo [3,4-b][1,3,4] thiadiazine derivatives, Journal of Advanced Pharmaceutical Technology and Research, 5, 90-95.

[10] N.Chaudharya, R.Dubeyb, H.Panwarc (2014) Designing, synthesis and pharmacology of some novel 4-\{4-(4-bromobenzyliden)amino\}piperidin-1yl)-5-aryl-3-thiol-4H-1,2,4-triazole, Der Pharma Chemica, 6, 115-119.

[11] T.Eicher, S.Hauptmann (2003) The Chemistry of Heterocycles: Structure, Reactions, Synthesis and Application, $2^{\text {nd }}$ ed., Wiley-VCH Verlag, Weinheim.

[12] A.Thakur (2005) QSAR Study on benzenesulfonamide DNA binding affinity: Physicochemical approach using surface tension, ARKIVOC, XIV, p. 49-53.

[13] L.Arman-Zubić, N.P.Janić, M.Lazarević (2000) A study of the behavior of some substituted 1,2,4triazoline-3-thiones in different media, Journal of Serbian Chemical Society, 65(9), 619-630.

[14] R.Katritzky, C.W.Rees (1984) Comprehensive Heterocyclic Chemistry-Five-membered Rings with Three or more Heteroatoms, each with their Fused Carbocyclic Derivatives, (Eds.), London, Pergamon Press LTD.

[15] V.Dimova, N.Perisic-Janjic (2007) Determination and QSAR study of the dissociation constants of some 4,5-disubsituted-2,4-dihydro-3h-1,2,4triazoline-3-thiones, Organic Chemistry: An Indian Journal, 3(2), 51-59.

[16] M.Jankulovska, I.Spirevska, K.C.Ragenovic (2006) Behaviour of some newly synthesized substituted 1,2,4-triazoline-3-thiones in sulfuric acid media, Bulletin of the Chemists and Technologists of Macedonia, 25(1), 29-37.

[17] M.Jankulovska, I.Spirevska, L.Šoptrajanova (2006) Determination of the dissociation constants of some newly synthesized derivatives of 1,2,4-triazoline-3thione in sodium hydroxide media, Bulletin of the Chemists and Technologists of Macedonia, 25(2), 99-106.

[18] K.C.Ragenovic, V.Dimova, V.Kakurinov, D.M.Gabor (2003) Synthesis of 1-Nonanoyl/octadecanoyl 1-4substituted Thiosemicarbazides and substituted $1,2,4$-Triazoles as biological active compounds, Journal of Hetrocyclic Chemistry, 40, 905-908.

[19] J.J.P.Steawart (1989) Optimization of Parameters for Semi-Empirical Methods I-Method., J. Comput. Chem., 10, 209-216.

[20] A.V.Stepanchikova, A.A.Lagunin, D.A.Filimonov, V.V.Poroikov (2003) Prediction of biological activity spectra for substances: Evaluation on the diverse sets of drug-like structures, Current Medicinal Chemistry, 10, 225-233. 
[21] H.C.Brown, P.W.R.Schleyer (1977) The NonClassical lon Problem, Plenum Press, New York.

[22] T.E.Edward, S.C.Wong (1977) Ionization of Carbonyl Compounds in Sulfuric Acid. Correction for Medium Effects by Characteristic Vector Analysis, Journal of American Chemical Society, 99, 4229-4232.

[23] R.A.Cox, K.Yates (1978) Excess Acidities. A Generalized Method for the Determination of Basicities in Aqueous Acid Mixtures, Journal of American Chemical Society, 100, 3861-3867.

[24] R.A.Cox (1987) Organic Reactions in Sulfuric Acid: The Excess Acidity Method, Journal of American Chemical Society, 20, 27-31.

[25] R.A.Cox, K.Yates (1983) Acidity functions: an update, Canadian Journal of Chemistry, 61, 22252243.

[26] R.A.Cox (2000) Advances in physical organic chemistry, Department of Chemistry of Toronto, Toronto, Ontario, Canada, Elsevier Inc.

[27] J.L.Simonds (1963) Application of Characteristic Vector analysis to Photographic and Optical Response Data, Journal of Optical Society of America, 53, 968-974.

[28] A.Albert, E.P.Serjeant (1971) The Determination of Ionization constants-A laboratory manual, Chapman and $\mathrm{Hal}, 2^{\mathrm{d}}$ edition, London and New York..

[29] T.Davis, T.A.Geissman (1954) Basic Dissociation Constants of Some Substituted Flavones, Journal of American Chemical Society, 76, 3507-3511.

[30] R.A.Cox, K.Yates (1981) Medium effects in protonation equilibrium studies. Accurate acidity ants using excess acidity method,Canadian Journal of Chemistry, 59, 1560-1573.

[31] B.Garcia, R.M.Casado, J.Castillo, S.lbeas, I.Domingo, J.M.Leal (1993) Acidity constants of benzamide and some ortho-substituted derivatives, Journal of Physical Organic Chemistry, 6, 101-106.

[32] C.Öğretir, İ.i..Öztürk, N.F.Tay (2007) Quantum chemical studies on tautomerism, isomerism and deprotonation of some 5(6)-substituted benzimidazole-2-thiones, ARKIVOC, XIV, 75-99.

[33] A.A.lkizler, R.Abbasoğlu, N.Saltek, M.Şerifova (1997) A Quantum - Chemical Ivestigation on 5,5' $\mathrm{BI}(1 \mathrm{H}-1,2,4$-triazole), Turkish Journal of Chemistry, 21, 353-362.

[34] A.Albert, E.P.Serjeant (1971) The Determination of Ionization constants-a laboratory manual, Chapman and $\mathrm{Hal}, 2^{\mathrm{d}}$ edition, London and New York.

[35] S.Karakuü, U.Çoruh, B.Barlas-Durgun, E.M. Vázquez-López, S.Özbaü-Turan, J.Akbuùa, S Rollas (2010) Synthesis and cytotoxic activity of some 1,2,4-triazoline-3-thione and 2,5-disubstituted1,3,4-thiadiazole derivatives, Marmara Pharmaceutical Journal, 14, 84-90.

[36] A.H.K.Sharba, R.H.Al-Bayati, N.Rezki, M.R.Aouad (2005) Synthesis of thiadiazoles and 1,2,4-triazoles derived from cyclopropane dicarboxylic acid. Molecules, 10, 1153-1160.

[37] N.Perisic-Janić, S.Podunavac-Kuzmanović, D. Vlaović (1994) Electronic spectra and ionization constants of newly synthesized derivatives 1 benzyl-2-amino 5,6dimethyl-benzimidazoles, Journal of Serbian Chemical Society, 59(10), 743-748.

\title{
IZVOD
}

\section{POREĐENJE TEORIJSKOG I EKSPERIMENTALNOG ISPITIVANJA PROCESA PROTONACIJE NEKIH TIONOVA U KISELIM MEDIJIMA}

PM3 poluempirijska metoda korišćena je za kvantno-hemijsko istraživanje kako bi se istražila elektronska svojstva $i$ odredio centar za protonaciju u 1,2,4-triazolin-3-tionu. Potvrda centra za protonaciju u kiselom mediju ispitivanih jedinjenja izvršena je korišćenjem vrednosti atomskog naboja, kao i vrednosti protonskog afiniteta. Rezultati poluempirijskih izračunavanja pokazali su da je centar za protonaciju u molekulu tiona bio atom sumpora. Ponašanje tiona ispitivano je $u$ mineralnom kiselinskom medijumu pomoću UV spektroskopije. Uticaj snage kiseline i priroda njenog aniona na proces protonacije diskutovana je korišćenjem tri različite mineralne kiseline za protonaciju (perhlorna, hlorovodonična $i$ fosforna kiselina). Proces protonacije $u$ perhlornoj $i$ hlorovodoničnoj kiselini odvijao se u jednom koraku, dok u fosfornoj kiselini nije završen ni kada je koncentracija imala maksimalnu vrednost. Vrednosti konstante disocijacije protoniranih oblika $(\mathrm{pKBH}+)$ i parametar solvatacije $m^{*}$ izračunate su u skladu sa metodom funkcije "višak kiselosti“ (Cox and Yates) koristeći podatke apsorpcije iz eksperimentalnih $i$ rekonstruisanih spektra (Karakteristična VektorskaAnaliza - CVA). Određene vrednosti $\mathrm{pKBH}+\mathrm{u}$ hlorovodoničnoj kiselini imale su više negativne vrednosti od onih dobijenih u medijumu perhlorne kiseline. Vrednosti pKBH+ bile su u saglasnosti sa literaturnim podacima za ovu klasu jedinjenja.

Ključne reči: 1,2,4-triazolin-3-tioni, protonacija, konstante disocijacije, afinitet protona, UVspektrofotometrija, PM3 poluempirijska metoda

\author{
Naučni rad \\ Rad primljen: 05. 08. 2020 \\ Rad prihvaćen: 10. 12. 2020. \\ Rad je dostupan na sajtu: www.idk.org.rs/casopis
}

(C) 2021 Authors. Published by Engineering Society for Corrosion. This article is an open access article distributed under the terms and conditions of the Creative Commons Attribution 4.0 International license (https://creativecommons.org/licenses/by/4.0/) 